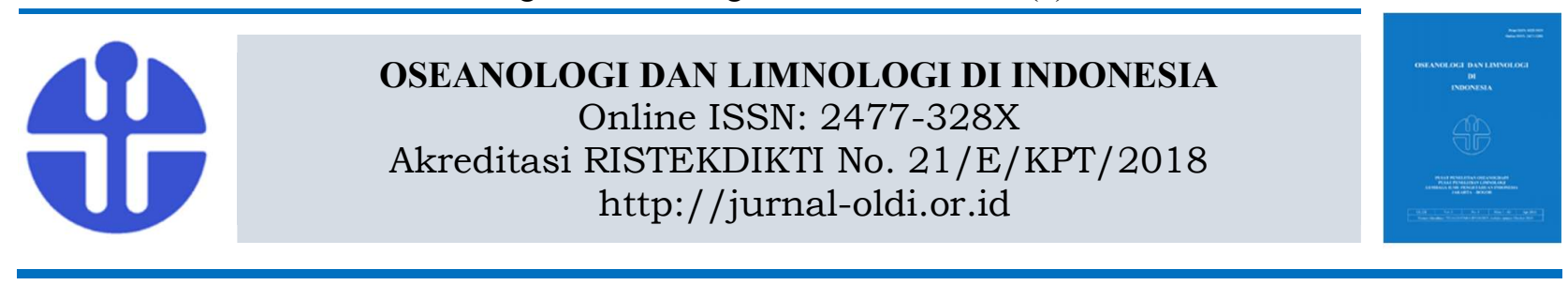

\title{
Pengukuran Total Petroleum Hidrokarbon (TPH) Melalui Pendekatan Kadar Minyak- Lemak dalam Sedimen di Perairan Delta Cimanuk, Jawa Barat
}

\author{
Ita Wulandari ${ }^{1}$, Deny Yogaswara ${ }^{1}$, Khozanah $^{1}$, Edward $^{1}$, Ricky Rositasari ${ }^{1}$ dan Dede Falahudin ${ }^{* 1}$ \\ ${ }^{1}$ Pusat Penelitian Oseanografi, Lembaga Ilmu Pengetahuan Indonesia \\ Jl. Pasir Putih I, Ancol Timur, Jakarta 14430, Indonesia \\ *Email: dede.falahudin@lipi.go.id
}

Submitted 9 May 2019. Reviewed 17 July 2019. Accepted 6 August 2019.

DOI: 10.14203/oldi.2019.v4i2.272

\begin{abstract}
Abstrak
Perairan delta Cimanuk terletak di muara sungai terpanjang kedua di Jawa Barat yaitu Sungai Cimanuk yang bermuara ke Laut Jawa di pesisir Indramayu. Limbah rumah tangga dan industri yang dibawa melalui Sungai Cimanuk berpotensi menjadi ancaman cemaran khususnya senyawa minyak dan lemak (Oil and Grease/OG). Aktivitas lalu lintas kapal penangkap ikan di pangkalan pendaratan ikan (PPI) dan pelabuhan perikanan (PP) di sekitar perairan sangat berpotensi menambah beban kontaminasi. Kontaminan minyak dan lemak (OG) berasal dari limbah yang berupa lemak hewani, nabati dan total petroleum hidrokarbon (TPH). Tujuan penelitian ini untuk mengestimasi konsentrasi dan distribusi spasial TPH dalam sedimen di perairan muara DAS Cimanuk berdasarkan kadar OG, dan mengidentifikasi sebaran wilayah yang tercemar TPH di perairan delta Cimanuk. Analisis OG dilakukan dengan alat spektrofotometer Fourier Transform Infrared (FTIR) dengan mode transmisi. Hasil penelitian menunjukkan bahwa konsentrasi OG dalam sedimen berkisar antara $<1$ sampai $138,10 \mathrm{mg} \mathrm{kg}^{-1}$ berat kering (bk), sementara estimasi nilai TPH yang merupakan salah satu fraksi penyusun OG berkisar antara $0,24-36,60 \mathrm{mg} \mathrm{kg}^{-1} \mathrm{bk}$. Sedimen dengan konsentrasi OG tertinggi terdapat di St-10 yang terletak di bagian timur laut Delta Cimanuk. Dibandingkan dengan nilai batas panduan kualitas sedimen menurut ANZECC (TPH: $280-550 \mathrm{mg} \mathrm{kg}^{-1} \mathrm{bk}$ ), tingkat TPH di 18 stasiun pengamatan masih berada dalam kisaran batas normal, demikian pula dengan konsentrasi OG. Meskipun demikian, tingginya potensi asupan pencemaran yang terus menerus di muara DAS Cimanuk akan menurunkan kemampuan ekosistem estuari dalam menjaga keseimbangan kualitas lingkungan dan mengancam biodiversitas perairan.
\end{abstract}

Kata kunci: cemaran, minyak dan lemak, TPH, sedimen, FTIR, Cimanuk.

\section{Abstract}

Determination of Total Petroleum Hidrokarbon (TPH) through the Concentration of Oil and Grease (OG) in the Surface Sediment of Cimanuk Delta Waters, West Java. The Estuary of Delta Cimanuk is located in the coastal water of Indramayu, West Java. The pollution in the Cimanuk Delta was originated from households and industrial waste on coastal dan upland areas. Coupled with the traffic activities of fishing vessels at the fish landing (PPI) and fishing port (PP) bases around the waters, oil and grease contamination would be a threat as pollution in Indramayu coastal area. The major source of OG component on coastal waters was animal and vegetal fat and total petroleum hydrocarbon (TPH). The objectives of the study are to estimate the concentration and spatial distribution of TPH in the sediments of the Cimanuk watershed based on OG levels, and identifying the distribution of TPH-contaminated areas. Fourier Transform Infrared Spectroscopy (FTIR) instrument was applied to determine OG compounds in the sediment samples. The results showed that OG concentrations in sediments were varied between $<1$ to $138.104 \mathrm{mg} \mathrm{kg}^{-1}$ dry weight (dw), 
Wulandari et al.

while TPH was estimated at $0.24-36.60 \mathrm{mg} \mathrm{kg}^{-1} \mathrm{dw}$. The highest concentrations of OG was observed on St10 in the northeast coast. Compared to the threshold value of sediments quality guidelines according to ANZECC (OG: 280-550 $\mathrm{mg} \mathrm{kg}^{-1} \mathrm{dw}$ ), the TPH levels in eighteen observation stations were within normal range. The increased pollutant intake in Cimanuk watershed will threat the estuary as well as its biodiversity.

Keywords: pollution, oil and grease, total petroleum hydrocarbon, sediment, FTIR, Cimanuk.

\section{Pendahuluan}

Konsentrasi dan sebaran minyak dan lemak (OG) yang terikat dalam sedimen dapat digunakan sebagai indikator tercemarnya suatu wilayah perairan. Hal ini disebabkan fraksi OG yang bersifat hidrofobik lebih kuat terikat pada organik karbon dalam sedimen dibandingkan yang terlarut dalam kolom air, sehingga konsentrasi dan sebarannya akan mudah terukur dalam sedimen (Gong et al., 2014). Beberapa komponen yang termasuk didalam OG yaitu lemak yang berasal dari hewan maupun tumbuhan hingga petroleum hidrokarbon (TPH) (Alade et al., 2011).

Total petroleum hydrocarbon (TPH) merupakan istilah yang digunakan untuk mendeskripsikan seluruh komponen kimia hidrokarbon organik dalam minyak bumi (ASTDR, 1999). Konsentrasi TPH digunakan untuk mengetahui tingkat kontaminasi minyak bumi yang biasanya berasal dari produk minyak bumi dan bahan bakar kendaraan (Speight, 2014). Aktivitas pengiriman kargo, minyak mentah pertambangan, kendaraan bermotor adalah aktivitas yang memiliki risiko tinggi sebagai sumber cemaran $\mathrm{TPH}$.

Secara fisik TPH yang terdapat dalam OG dapat meningkatkan radiasi ultraviolet yang mengganggu ekosistem laut (Nordborg et al., 2018). Selain itu, ancaman zat karsinogenik dalam komponen TPH seperti polycyclic aromatic hydrocarbons (PAH) dapat terakumulasi dalam jaringan organisme (Neff, 2002). Semakin tinggi tingkat trofik dalam rantai makanan (Carpenter, 2013), maka akumulasi zat karsinogenik tersebut akan meningkat (Kwok et al., 2013).

Perairan Delta Cimanuk merupakan perairan tempat bermuaranya Sungai Cimanuk dan beberapa sungai kecil lainnya yang berhulu di kaki Gunung Papandayan, Kabupaten Garut dengan panjang sungai mencapai $182 \mathrm{~km}$. Aktivitas manusia yang intens di DAS Cimanuk mulai dari hulu sampai hilir menyebabkan adanya peningkatan potensi pencemaran dari limbah (Sutriati, 2011) yang dihasilkan, misalnya dari kegiatan pertanian (Sumatera, 1982), perikanan (Amirullah et al., 2012), industri (Gitarama et al., 2016) ataupun pemukiman (Pakpahan \& Syafa'at,
1991). Selain itu, aktivitas di perairan Indramayu juga dapat berpotensi sebagai sumber pencemaran di estuari Delta Cimanuk, seperti aktivitas pengeboran minyak (Setiawan, 2017) dan kegiatan perikanan tangkap di sekitar Delta Cimanuk seperti pelabuhan perikanan (PP) dan pangkalan pendaratan ikan (PPI). Dua pelabuhan diantaranya PP Cangkring dan PP Karangsong, PPI Tegalagung, Dadap, Juntinyuat, Lombang, Limbangan, Majakerta, Brondong, Singaraja, Eretan Wetan, Eretan Kulon, Sukahaji dan Ujung Gebang (Handayani et al., 2018). Keberadaan pelabuhan dan PPI memfasilitasi nelayan dalam proses distribusi ikan namun dapat berpotensi menimbulkan cemaran OG yang berasal dari kapal penangkap ikan tersebut.

Penelitian untuk mengetahui konsentrasi TPH sebagai komponen OG telah banyak dilakukan di beberapa perairan seperti Teluk Kuwait (de Mora et al., 2010), Teluk Persia (Tehrani et al., 2013), Bohai Sea, Cina (Zhou et al., 2014), Estuari Delaware (Kim et al., 2018), dan Laut Sumba (Yogaswara \& Khozanah, 2018). Informasi terkait pencemaran TPH berdasarkan kadar OG dapat memberikan informasi penting mengenai tingkat pencemaran akibat aktifitas antropogenik di perairan DAS Cimanuk yang belum banyak dilaporkan. Oleh karena itu, penelitian ini dilakukan untuk mengestimasi konsentrasi dan distribusi spasial TPH dalam sedimen perairan DAS Cimanuk berdasarkan kadar OG, dan mengidentifikasi sebaran wilayah yang tercemar TPH tersebut.

\section{Metodologi}

\section{Lokasi Sampling Sedimen}

Sampel sedimen permukaan diambil menggunakan Van Veen Grab dari 18 stasiun di sekitar perairan DAS Cimanuk, Kabupaten Indramayu, Jawa Barat. Stasiun dipilih berdasarkan jarak dari garis pantai menuju laut lepas (Gambar 1). Sampel sedimen permukaan (kedalaman $\pm 10 \mathrm{~cm}$ ) diambil menggunakan sendok stainless steel, disimpan dalam botol kaca dan dibawa dengan ice box berpendingin untuk analisis konsentrasi OG di laboratorium. 


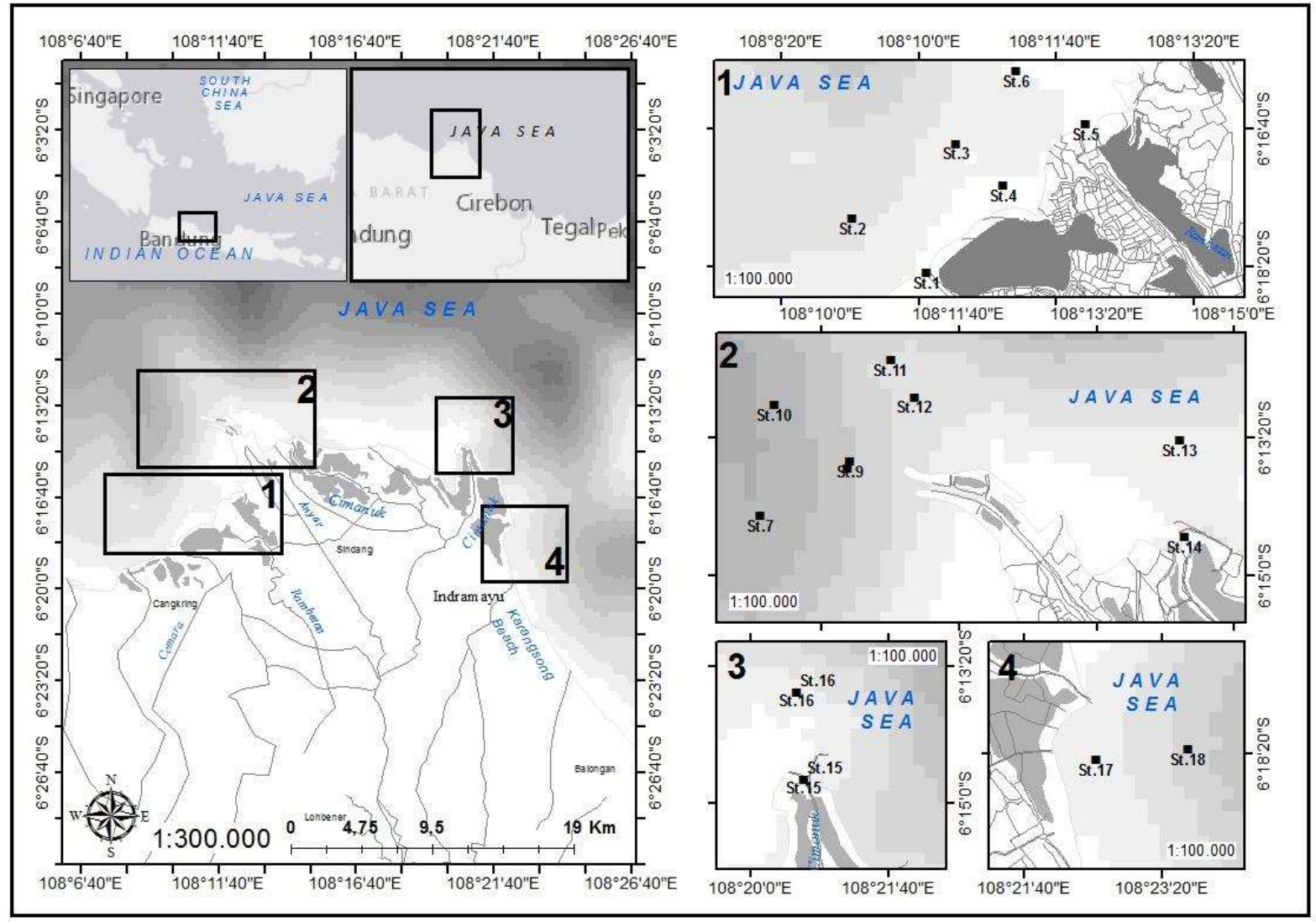

Gambar 1. Peta lokasi pengambilan sampel di perairan Delta Cimanuk dalam empat area (1-4).

Figure 1. Map of sampling locations in Cimanuk Delta waters divided into four areas (1-4).

\section{Analisis Oil and Grease}

Metode analisis OG dalam sedimen mengikuti metode ASTM D7066 seperti yang sudah dilakukan oleh Yogaswara dan Khozanah (2018) dengan sedikit modifikasi yaitu pada berat sedimen yang dianalisis dan metode ekstraksinya. Secara detail, sedimen ditimbang sebanyak 10 gram, ditambahkan $\mathrm{Na}_{2} \mathrm{SO}_{4}$ sampai kering, lalu diekstraksi sebanyak tiga kali ulangan menggunakan pelarut organik dichloromethane (DCM) sebanyak $30 \mathrm{ml}$, n-hexane $30 \mathrm{ml}$, dan campuran dichloromethane dan $\mathrm{n}$-hexane $(1: 1 \mathrm{v} / \mathrm{v})$ sebanyak $30 \mathrm{ml}$. Setelah itu, hasil ekstraksi diuapkan dengan rotary vapor $(\mathrm{t}=60$ menit, $\mathrm{T}=40$ $\left.{ }^{\circ} \mathrm{C}\right)$ sampai $1 \mathrm{ml}$ dan pelarutnya diganti dengan pelarut tetrachloroetilen (TCE) sebanyak $4 \mathrm{ml}$. Hasil ekstraksi dalam pelarut TCE langsung diukur nilai absorbansinya dengan alat Fourier Transform Infrared (FTIR) iS5 (Thermo Scientific, USA) dengan panjang gelombang 2850-2950 $\mathrm{cm}^{-1}$. Konsentrasi OG dinyatakan dalam satuan $\mathrm{mg} \mathrm{kg}^{-1}$ berat kering (bk) dan konsentrasi di bawah batas pengukuran dinyatakan sebagai konsentrasi kurang dari satu $\left(<1 \mathrm{mg} \mathrm{kg}^{-1} \mathrm{bk}\right)$.

\section{Estimasi Nilai TPH}

Konsentrasi TPH ( $\left.\mathrm{mg} \mathrm{kg}^{-1} \mathrm{bk}\right)$ berbanding lurus dengan dengan konsentrasi OG ( $\left.\mathrm{mg} \mathrm{kg}^{-1} \mathrm{bk}\right)$ dan konsentrasi TPH diestimasi berdasarkan persamaan (1) dari Rauckyte et al. (2010):

$$
[\mathrm{TPH}]=0,0316[\mathrm{OG}]+781,04
$$

\section{Analisis Ukuran Partikel dan Kalkulasi Porositas Sedimen}

Ukuran partikel sedimen dianalisis dengan metode granulometri. Sedimen yang telah dikeringkan $\quad\left(\mathrm{T}=80 \quad{ }^{\circ} \mathrm{C}, \quad \mathrm{t}=12\right.$ jam $) \quad$ lalu dihomogenkan dengan air, lalu disaring dengan ayakan bertingkat untuk memisahkan sedimen dengan ukuran mesh $64 ; 32 ; 16 ; 8 ; 4 ; 2 ; 1 ; 0,5$; 0,$25 ; 0,125 ; 0,063$; and $0,004 \mathrm{~mm}$. Persentase jenis sedimen dianalisis berdasarkan skala Wentworth (Wentworth, 1922).

Kalkulasi nilai porositas sedimen dilakukan berdasarkan teori bahwa satu gram air sama dengan satu sentimeter kubik air, artinya massa air dalam gram sama dengan massa air dalam sentimeter kubik. Ketika sampel dalam keadaan basah, semua pori terisi oleh air, sehingga volume pori sama dengan volume air dalam sampel basah. Nilai porositas sedimen diukur menggunakan persamaan (2) menurut $\mathrm{Yu}$ et al. (2015) 
Wulandari et al.

$$
P t=\frac{V_{p}}{V_{t}} \times 100 \%
$$

Persentase porositas ( $P t)$ merupakan perbandingan antara volume pori $\left(C_{W}\right)$ berbanding terbalik dengan total volume $\left(V_{t}\right)$.

\section{Tingkat Kontaminasi TPH di Lingkungan}

Pengukuran tingkat kontaminasi sedimen di perairan delta Cimanuk dilakukan dengan membandingkan nilai OG dengan baku mutu sedimen. Namun karena baku mutu untuk OG tidak tersedia, maka salah satu komponennya yaitu TPH digunakan sebagai acuan. Meskipun nilai baku mutu ini tidak dapat digunakan sebagai indikator toksisitas bagi biota laut, tetapi dapat digunakan untuk memperkirakan tingkat pencemaran di lingkungan. Hingga saat ini di Indonesia belum memiliki baku mutu untuk tingkat kontaminasi TPH di sedimen, oleh karena itu dalam penelitian ini digunakan baku mutu beberapa negara seperti Amerika Serikat, Australia, Kanada, China dan Norwegia.

Pendekatan yang dipakai dalam menentukan baku mutu sedimen sangat bervariasi, sebagai contoh Amerika Serikat melalui National Oceanic and Atmospheric Administration (NOAA) menentukan baku mutu berdasarkan Effect Range Medium dan Low (ER-M, ER-L) (Long and Mogran, 1990), Australian and New Zealand Environment and Conservation Council (ANZECC) berdasarkan Sediment Quality Guideliness Value dan High Value (SQG-Value, SQG-High Value) (Simpson et al., 2013). Kanada melalui Canadian Council of Ministers of the Environment (CCME) mengeluarkan nilai baku mutu berdasarkan ukuran sedimen (CCME, 2001). China mengelompokkannya berdasarkan grade, yaitu sedimen yang cukup bersih digolongkan dalam Grade-I yang dapat dimanfaatkan untuk marikultur, wilayah konservasi dan aktivitas manusia seperti berenang; sedimen yang terkontaminasi sedang digolongkan dalam GradeII dapat digunakan untuk industri dan situs pariwisata; dan sedimen yang tergolong Grade-III yaitu untuk sektor transportasi seperti pelabuhan (Zhou et al., 2014). Adapun Norwegia mengeluarkan batasan pencemaran TPH berdasarkan fraksi alifatik hidrokarbon yang disusun berdasarkan saran Badan Perlindungan Lingkungan dan Institut Petroleum Swedia (Eilen et al., 1999).

Tabel 1. Baku mutu sedimen untuk TPH dari beberapa negara.

Table 1. Sediment quality standards for TPH from several countries.

\begin{tabular}{|c|c|c|c|c|}
\hline SQG & & & $\begin{array}{l}\text { Concentration (mg } \\
\mathrm{kg}^{-1} \text { dry weight } \\
\text { sediment) }\end{array}$ & References \\
\hline \multirow[t]{2}{*}{$\begin{array}{l}\text { ER-L/ER-M } \\
\text { Based }\end{array}$} & NOAA 90 & $\begin{array}{l}\text { ER-L } \\
\text { ER-M }\end{array}$ & $\begin{array}{l}4 \\
35\end{array}$ & $\begin{array}{l}\text { (Long \& Mogran, } \\
1990)\end{array}$ \\
\hline & ANZECC & $\begin{array}{l}\text { SQG-Value } \\
\text { SQG-High Value }\end{array}$ & $\begin{array}{l}280 \\
550\end{array}$ & $\begin{array}{l}\text { (Simpson et al., } \\
\text { 2013) }\end{array}$ \\
\hline \multirow[t]{3}{*}{ Various } & CCME & $\begin{array}{l}\text { Coarse Grain } \\
\text { Fraction } 1 \\
\text { Fraction } 2 \\
\text { Fraction } 3 \\
\text { Fraction } 4 \\
\text { Fine Grain } \\
\text { Fraction } 1 \\
\text { Fraction } 2 \\
\text { Fraction } 3 \\
\text { Fraction } 4\end{array}$ & $\begin{array}{l}30 \\
150 \\
300 \\
2800 \\
\\
210 \\
150 \\
1300 \\
5600\end{array}$ & (CCME, 2001) \\
\hline & China & $\begin{array}{l}\text { Grade } 1 \\
\text { Grade } 2 \\
\text { Grade } 3\end{array}$ & $\begin{array}{l}500 \\
1000 \\
1500\end{array}$ & $\begin{array}{l}\text { (Zhou et al., } \\
\text { 2014) }\end{array}$ \\
\hline & $\begin{array}{l}\text { Norwegian } \\
\text { Pollution Control } \\
\text { Autority }\end{array}$ & $\begin{array}{l}\text { Aliphatics C5-C10 } \\
\text { Aliphatics }>\mathrm{C} 10-\mathrm{C} 12 \\
\text { Aliphatics }>\mathrm{C} 12-\mathrm{C} 35\end{array}$ & $\begin{array}{l}7 \\
30 \\
100\end{array}$ & $\begin{array}{l}\text { (Eilen et al., } \\
\text { 1999). }\end{array}$ \\
\hline
\end{tabular}




\section{Analisis Data}

Analisis data telah dilakukan dengan software Microsoft Excel. Distribusi spasial dan konsentrasi TPH dalam sedimen dilakukan dengan analisis statistik regresi linier. Uji korelasi digunakan untuk mengetahui distribusi spasial TPH terhadap perbedaan kedalaman, porositas partikel sedimen dan ukuran partikel sedimen.

\section{Hasil}

\section{Konsentrasi dan Distribusi OG dan TPH}

Konsentrasi OG pada sedimen di perairan Delta Cimanuk berkisar antara $<1-138,10 \mathrm{mg} \mathrm{kg}$ ${ }^{1}$ bk (rata-rata+SD: $22,53 \pm 8,80 \mathrm{mg} \mathrm{kg}^{-1}$ bk). Estimasi nilai TPH yang merupakan salah satu fraksi penyusun dalam OG berkisar antara 0,24 $36,60 \mathrm{mg} \mathrm{kg}^{-1}$ bk (rata-rata+SD: $3,28 \pm 5,65 \mathrm{mg} \mathrm{kg}^{-}$

${ }^{1}$ bk). Sedimen dengan konsentrasi OG dan TPH tertinggi terdapat pada stasiun 10 di bagian timur laut Delta Cimanuk (OG: 138,10 mg kg-1 bk; estimasi TPH: $11,60-36,60 \mathrm{mg} \mathrm{kg}{ }^{-1} \mathrm{bk}$ ), sedangkan tiga stasiun dengan nilai dibawah batas deteksi $\left(<1 \mathrm{mg} \mathrm{kg}^{-1}\right.$ bk) yaitu stasiun 4,12 , dan 14 (Tabel 2).

Distribusi nilai estimasi TPH dalam sedimen di perairan Delta Cimanuk dipengaruhi oleh berbagai faktor diantaranya ukuran partikel sedimen, porositas partikel, dan kedalaman atau jarak lokasi pengambilan sedimen. Hasil analisis korelasi menunjukkan bahwa nilai estimasi TPH memiliki hubungan positif dengan porositas sedimen, namun korelasi antara dua variabel yang terukur di lokasi penelitian memiliki hubungan sangat lemah $\left(\mathrm{y}=0,1614 \mathrm{x}-0,4968 ; \mathrm{R}^{2}=0,09\right)$. Begitu pula hasil korelasi antara nilai TPH dan kedalaman lokasi sedimen menunjukkan hubungan positif dengan kadar korelasi yang sangat lemah (y $\left.=0,0256 \mathrm{x}+0,2066 ; \mathrm{R}^{2}=0,06\right)($ Gambar 2).

Tabel 2. Konsentrasi OG, TPH dan karakteristik sedimen.

Tabel 2. Concentration of OG and TPH with surface bottom sediment characteristic.

\begin{tabular}{|c|c|c|c|c|c|c|}
\hline I.D. & $\begin{array}{l}\text { Depth } \\
\text { (m) }\end{array}$ & $\begin{array}{l}\text { Moisture } \\
\text { Content } \\
(\%)\end{array}$ & $\begin{array}{l}\text { Porosity } \\
\text { (\%) }\end{array}$ & $\begin{array}{c}\mathrm{OG} \\
\left(\mathrm{mg} \mathrm{kg}^{-1} \mathrm{bk}\right)\end{array}$ & $\begin{array}{c}\text { Estimasi TPH } \\
\left(\mathrm{mg} \mathrm{kg}^{-1} \mathrm{bk}\right)\end{array}$ & $\begin{array}{c}\text { Sediment } \\
\text { Characteristic }\end{array}$ \\
\hline St-1 & 0.5 & 54.92 & 5.51 & 5.58 & $0.47-1.48$ & Clayish Silt \\
\hline St-2 & 3 & 50.04 & 5.02 & 6.40 & $0.54-1.70$ & Silt \\
\hline St-3 & 3 & 41.61 & 4.18 & 7.57 & $0.64-2.01$ & Silt \\
\hline St-4 & 0.5 & 11,96 & 1,20 & $<1$ & - & Silty Sand \\
\hline St-5 & 0.5 & 36.94 & 3.72 & 30.86 & $2.59-8.18$ & Silty Sand \\
\hline St-6 & 2 & 58.19 & 5.88 & 2.85 & $0.24-0.76$ & Clayish Silt \\
\hline St-7 & 8 & 50.28 & 5.06 & 4.95 & $0.42-1.31$ & Silt \\
\hline St-8 & 0.5 & 52.56 & 5.27 & 32.04 & $2.69-8.49$ & Silt \\
\hline St-9 & 1 & 38.49 & 3.87 & 10.95 & $0.92-2.90$ & Silt \\
\hline St-10 & 12 & 67.03 & 6.71 & 138.10 & $11.60-36.60$ & Silt \\
\hline St-11 & 12 & 54.45 & 5.46 & 18.78 & $1.58-4.98$ & Clayish Silt \\
\hline St-12 & 2 & 61.84 & 6.22 & $<1$ & - & Silt \\
\hline St-13 & 10 & 51.80 & 5.19 & 8.80 & $0.74-2.33$ & Clayish Silt \\
\hline St-14 & 2 & 28.26 & 2.83 & $<1$ & - & Sand \\
\hline St-15 & 2 & 42.06 & 4.22 & 7.77 & $0.65-2.06$ & Silt \\
\hline St-16 & 7 & 56.20 & 5.62 & 11.14 & $0.94-2.95$ & Silt \\
\hline St-17 & 3 & 58.47 & 5.89 & 46.85 & $3.94-12.42$ & Silt \\
\hline St-18 & 7 & 50.18 & 5.11 & 5.27 & $0.44-1.40$ & Silt \\
\hline Mean & 4.22 & 48.07 & 4.83 & 22.53 & $1.89-5.97$ & \\
\hline Median & 2.50 & 51.04 & 5.15 & 8.80 & $0.74-2.33$ & \\
\hline
\end{tabular}


Wulandari et al.
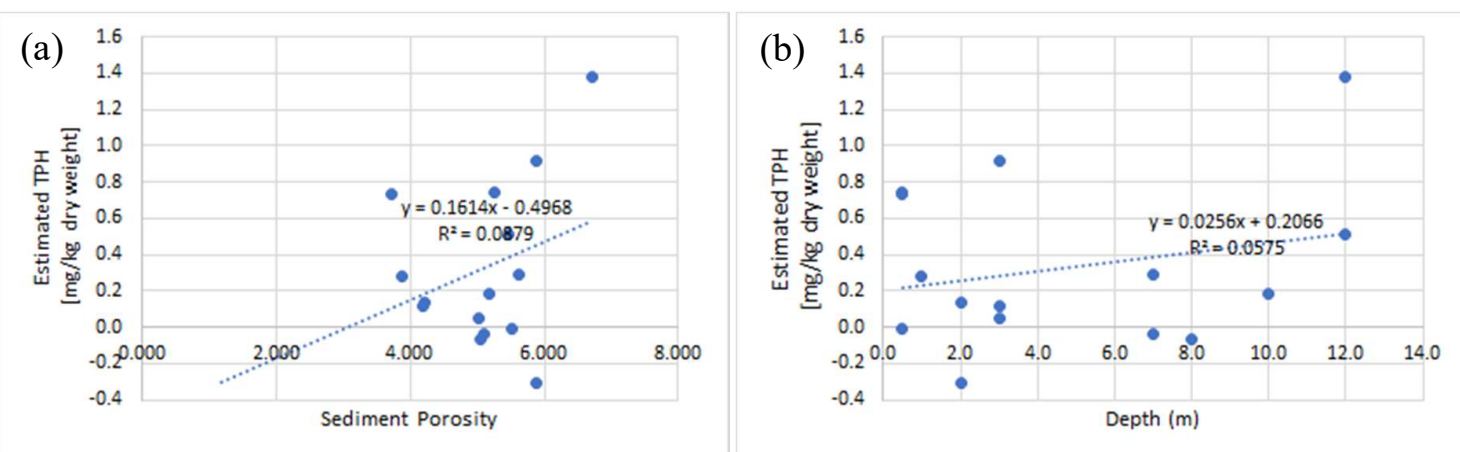

Gambar 2. Korelasi konsentrasi TPH dengan kedalaman perairan (a) dan porositas sedimen (b). Figure 2. Correlation of TPH concentration vs water depth (a) and sediment porosity (b).

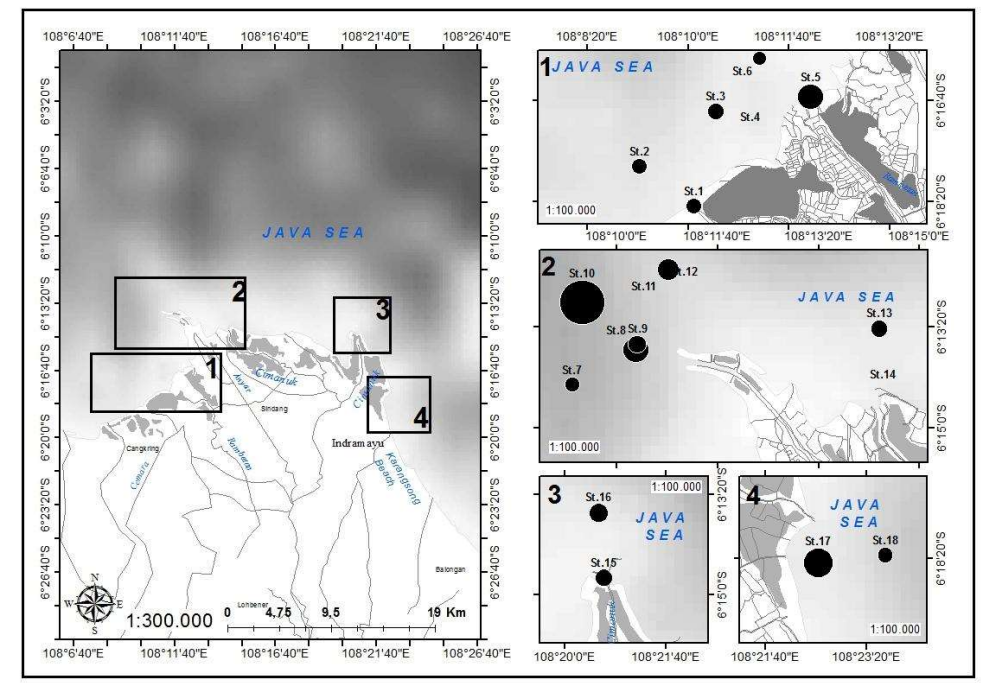

Gambar 3. Distribusi TPH dalam sedimen di perairan estuari delta Cimanuk, ukuran noktah menunjukkan konsentrasi TPH ( $\left.\mathrm{mg} \mathrm{kg}^{-1} \mathrm{bk}\right)$.

Figure 3. Distribution of TPH in the surface sediments of the Delta Cimanuk waters, dot size indicates concentration of TPH $\left(\mathrm{mg} \mathrm{kg}^{-1} \mathrm{dw}\right)$.

\section{Pembahasan}

Konsentrasi fraksi TPH dalam OG di sedimen perairan Delta Cimanuk memiliki variasi yang tinggi antar stasiun. Hal tersebut disebabkan oleh berbagai faktor, salah satunya jarak antara stasiun pengamatan dengan lokasi sumber pencemaran. Penelitian yang dilakukan oleh (Setiawan, 2017) menunjukkan bahwa banjir sering terjadi di Sungai Cimanuk yang menyebabkan tingginya masukan polutan antropogenik di wilayah delta Cimanuk (Gitarama et al., 2016). Hal tersebut teramati di stasiun 5, 10, dan 17 yang lokasinya sangat dekat dengan muara sungai. Selain itu, tingginya konsentrasi fraksi TPH di beberapa stasiun yang jauh dari daratan seperti di stasiun 16 dan 8 , ada kemungkinan sumber pencemarannya bukan dari aktivitas di daratan, tapi aktivitas di laut seperti lalu lintas perahu nelayan ataupun pengeboran minyak. Di

Kabupaten Indramayu terdapat beberapa titik lokasi pengeboran minyak bumi, yaitu di daerah Cangkring (Setiawan, 2017), Losarang, dan Balongan. Hal tersebut mengindikasikan bahwa asupan dari daratan sebagai sumber utama pencemaran TPH di perairan estuari.

Distribusi TPH pada sedimen di muara DAS Cimanuk menunjukkan terjadi penurunan kadar TPH seiring semakin jauh dari muara sungai. Hal tersebut menunjukkan bahwa distribusi partikel tersuspensi lebih dipengaruhi oleh arus sungai daripada arus pasang surut (Rullyanto et al., 2007) sehingga partikel sedimen tersuspensi yang membawa dan mengendapkan pencemar organik terakumulasi di muara, seperti yang teramati di stasiun 10 yang lebih dekat ke daratan. Selain itu, kondisi dinamika air sungai yang sangat fluktuatif menyebabkan tingginya partikel yang tersuspensi 
dalam kolom air (Sutriati, 2011; Gitarama et al., 2016) dan secara langsung meningkatkan laju pencampuran yang intensif antara partikel sedimen dengan pencemar.

Selanjutnya, hasil uji korelasi antara distribusi TPH dengan kerapatan porositas dan kedalaman lokasi sampling menunjukkan hubungan positif namun derajat korelasinya yang lemah. Hal tersebut menunjukkan bahwa distribusi senyawa TPH banyak terikat dalam partikel sedimen yang memiliki luas permukaan dan nilai kerapatan porositas yang besar misalkan lanau dan lempung (Yi et al., 2016), sehingga memengaruhi perbedaan kemampuan sedimen dalam menyerap hidrokarbon minyak bumi (Okop \& Ekpo, 2012). Selain itu, derajat korelasi yang lemah antara distribusi TPH dan porositas sedimen dapat disebabkan oleh tingginya variasi kadar lanau dalam sedimen. Secara umum dominasi sedimen dasar di lokasi penelitian adalah lanau, yang berasal dari perpindahan sedimen wilayah terestrial di sekitar DAS Cimanuk (Sulaksana et al., 2013). Heterogenitas sedimen berperan penting dalam mengendalikan konsentrasi kontaminan, efisiensi remediasi lebih tinggi pada sedimen pasir daripada lempung dan lanau (Abdel-Moghny et al., 2012). Perbedaan ini dapat dijelaskan oleh struktur partikulat sedimen berpasir yang jauh lebih longgar dari sedimen berlumpur yang lengket dan dengan plastisitas yang jauh lebih tinggi (Link, 1966).

Adapun terkait dengan kedalaman, hubungan positif menunjukkan bahwa adanya proses penumpukan sedimen yang mengikat TPH lebih jauh dari muara sungai. Hal tersebut dapat disebabkan oleh dorongan kuat dari banjir yang sering terjadi di sungai Cimanuk ataupun kontaminasi dari tingginya aktivitas nelayan di perairan sekitar Delta Cimanuk (Savitri \& Pramono, 2017). Korelasi antara kedalaman dan konsentrasi TPH terdeteksi sangat lemah, karena distribusi TPH di sekitar Delta Cimanuk sangat bervariasi pada setiap kedalaman.

DAS Cimanuk yang terletak di pesisir utara Jawa saat ini merupakan wilayah dengan skala dan diversitas pembangunan sangat pesat seperti yang juga dilaporkan oleh Fakhrudin dan Daruati (2017), sehingga beban kontaminasi diproyeksikan akan terus meningkat. TPH adalah salah satu kontaminan yang perlu terus dipantau untuk mengurangi dampak kerugian ekonomis dan ekologis. Kim et al. (2018) telah melaporkan bahwa salah satu sumber asal TPH di suatu perairan adalah limbah kegiatan domestik dan industri. Sebagai gambaran tentang ancaman kontaminasi TPH pada suatu perairan pada Tabel 3 dapat dilihat kondisi beberapa perairan yang tengah menghadap ancaman, meskipun metode yang digunakan berbeda. Sumber kontaminan TPH setiap wilayah sangat spesifik, seperti di perairan Sumba ditemukan bahwa sumber kontaminasi diduga kuat berasal dari aktivitas lalu lintas pelayaran (Yogaswara \& Khozanah, 2018).

Kadar TPH di semua stasiun penelitian masih dalam batas normal saat dibandingkan dengan baku mutu sedimen menurut ANZECC (TPH: $280-550 \mathrm{mg} \mathrm{kg}^{-1}$ bk). Baku mutu tersebut digunakan karena secara geografis lokasinya dekat dengan Indonesia dan memiliki batas bawah yang rendah sehingga masih dapat mengakomodasi proses hayati biota yang sangat sensitif terhadap kontaminasi minyak bumi. Beberapa penelitian melaporkan bahwa pencemaran akibat kontaminasi TPH yang melebihi ambang batas baku mutu dapat menyebabkan kerusakan dalam pertumbuhan mikroalga (Ramadass et al., 2017), terumbu karang (Suhery et al., 2017) dan ikan (Webby \& Ling, 2016). Meskipun kondisi saat ini nilai TPH masih sesuai baku mutu sedimen ANZECC, pemantauan kadar TPH harus terus dilaksanakan karena adanya potensi ancaman yang tinggi dari limbah aktivitas antropogenik di sekitar DAS Cimanuk dan Delta Cimanuk (Sodikin, 2011). Oleh karena itu, upaya mitigasi pencemaran dan degradasi lingkungan perlu dilakukan misalnya melalui penetapan wilayah konservasi di sekitar bantaran DAS Cimanuk (Susetyaningsih, 2012) dan membagi informasi terkait kondisi lingkungan perairan kepada pemangku kepentingan.

Tabel 3. Konsentrasi TPH dalam sedimen di beberapa lokasi dalam $\mathrm{mg} \mathrm{kg}^{-1} \mathrm{bk}(\mathrm{ppm})$. 
Wulandari et al.

Table 3. The concentration of TPH in sediments at several locations in $\mathrm{mg} \mathrm{kg}^{-1} \mathrm{dw}(\mathrm{ppm})$.

\begin{tabular}{|c|c|c|c|c|}
\hline \multirow{2}{*}{ Location } & \multicolumn{2}{|c|}{ Concentration } & \multirow{2}{*}{ Method } & \multirow{2}{*}{ Reference } \\
\hline & Range & Mean & & \\
\hline Kuwait Bay & $2-251$ & 44 & $\begin{array}{l}\text { UV Fluorescence } \\
\text { Spectroscopy }\end{array}$ & $\begin{array}{l}\text { (de Mora et al., } \\
2010)\end{array}$ \\
\hline North Persian Gulf & $16.48-97.15$ & 50.65 & $\begin{array}{l}\text { UV Fluorescence } \\
\text { Spectroscopy }\end{array}$ & $\begin{array}{l}\text { (Tehrani et al., } \\
\text { 2013) }\end{array}$ \\
\hline Bohai Sea, China & $6.3-535$ & 159 & $\begin{array}{l}\text { UV Fluorescence } \\
\text { Spectroscopy }\end{array}$ & $\begin{array}{l}\text { (Zhou et al., } \\
2014 \text { ) }\end{array}$ \\
\hline $\begin{array}{l}\text { Delaware estuary, } \\
\text { USA }\end{array}$ & $38-616$ & 271 & TLC-FID & (Kim et al., 2018) \\
\hline Sumba Sea, Indonesia & $<1-4.35$ & 2.40 & FTIR & $\begin{array}{l}\text { (Yogaswara \& } \\
\text { Khozanah, 2018) }\end{array}$ \\
\hline $\begin{array}{l}\text { Cimanuk watershed } \\
\text { estuary, Indonesia }\end{array}$ & $0.24-36.60$ & 3.28 & FTIR & This Study \\
\hline
\end{tabular}

\section{Kesimpulan}

Kadar pencemaran TPH dalam sedimen di perairan Delta Cimanuk masih dalam kategori batas normal berdasarkan baku mutu sedimen dari ANZECC dan beberapa negara lainnya. Meskipun demikian, kondisi perairan Delta Cimanuk berpotensi semakin menurun jika pengelolaan limbah domestik di sepanjang DAS Cimanuk tidak dapat dikendalikan. Oleh karena itu, monitoring kadar OG tersebut perlu dilakukan secara periodik. Selain itu, data monitoring tersebut dapat digunakan untuk mengetahui pola masukan pencemar antropogenik dari daratan yang terintegrasi dalam tata kelola sumber daya pesisir di Kabupaten Indramayu berkelanjutan.

\section{Persantunan}

Penelitian ini didanai dari kegiatan penelitian Prioritas Kedeputian IPK tahun anggaran 2017 dan Riset Prioritas LIPI melalui program Coral Reef Management and Rehabilitation - Coral Triangle Initiative (COREMAP-CTI) Phase 3 TA 2018 "Marine Debris and Pollution". Kami juga mengucapkan terima kasih kepada Bapak Herman Rahayaan dan Singgih Prasetyo A.W., A. Md yang membantu dalam kegiatan penelitian ini.

\section{Daftar Pustaka}

Abdel-Moghny, T., Mohamed, R. S. A., El-Sayed, E., Mohammed Aly, S., \& Snousy, M. G. (2012). Effect of Soil texture on remediation of hydrocarbons-contaminated soil at ElMinia District, Upper Egypt. ISRN Chemical Engineering. https://doi.org/10.5402/2012/406598

Alade, A. O., Jameel, A. T., Muyubi, S. A., Karim,
M. I. A., \& Alam, M. Z. (2011). Removal of oil and grease as emerging pollutants of concern (EPC) in Wastewater Stream. IIUM Engineering Journal, 12 (Special Issue on Biotechnology), 161-169. https://doi.org/ 10.31436/iiumej.v12i4.218

Amirullah, S., Dhahiyat, Y., \& Rustikawati, I. (2012). Intensitas dan prevalensi ektoparasit pada ikan di hulu Sungai Cimanuk, Kabupaten Garut, Jawa Barat. Jurnal Perikanan dan Kelautan, 3(4), 271-282.

ASTDR. (1999). Toxicological Profile for total petroleum hydrocarbons (TPH). U.S. Department of Health and Human Services, Public Health Service. Atlanta, GA.

Carpenter, D. O. (2013). Effects of Persistent and Bioactive Organic Pollutants on Human Health (Google eBook). Retrieved from http://books.google.com/books?hl=en\&lr= $\& \mathrm{id}=\mathrm{iR} 0 \mathrm{oAAAAQBAJ} \&$ pgis $=1$

CCME. (2001). Canada-Wide Standards (CWS) for Petroleum Hydrocarbons (PHC) in Soil. CCME Council of Ministers. Winnipeg.

de Mora, S., Tolosa, I., Fowler, S. W., Villeneuve, J. P., Cassi, R., \& Cattini, C. (2010). Distribution of petroleum hydrocarbons and organochlorinated contaminants in marine biota and coastal sediments from the ROPME Sea Area during 2005. Marine Pollution Bulletin, 60(12), 2323-2349. https://doi.org/10.1016/j.marpolbul.2010.09 .021

Eilen, A.V., Gijsbert, B. \& Terje, F. (1999). Guidelines for the Risk Assessment of Contaminated Sites. Oslo. https:// doi.org/82-7655-192-0

Fakhrudin, M., \& Daruati, D. (2017). Zonasi resapan air hujan sebagai dasar konservasi sumber daya air DAS Cimanuk. Limnotek Perairan Darat Tropis di Indonesia, 24(1), 
Oseanologi dan Limnologi di Indonesia 2019 4(2):123-132

26-35. Retrieved from https:// www.limnotek.or.id

Gitarama, A. M., Krisanti, M., \& Ratih Agungpriyono, D. (2016). Macrozoobenthic Communities and Accumulation of Chromium in Cimanuk Lama River, West Java. Jurnal Ilmu Pertanian Indonesia, 21(1), 48-55. https://doi.org/10.18343 /jipi.21.1.48

Gong, Y., Zhao, X., Cai, Z., O’Reilly, S. E., Hao, X., \& Zhao, D. (2014). A review of oil, dispersed oil and sediment interactions in the aquatic environment: Influence on the fate, transport and remediation of oil spills. Marine Pollution Bulletin, 79(1-2), 16-33. https://doi.org/10.1016/j.marpolbul.2013.12 .024

Handayani, D. A., Sukawi, \& Darmawan, E. (2018). Pengembangan Kawasan TPI Tegalagung Indramayu. Universitas Diponegoro. Retrieved from http:// eprints.undip.ac.id/59910/

Kim, A. W., Vane, C. H., Moss-Hayes, V., Engelhart, S. E., \& Kemp, A. C. (2018). $\mathrm{PAH}, \mathrm{PCB}, \mathrm{TPH}$ and mercury in surface sediments of the Delaware River Estuary and Delmarva Peninsula, USA. Marine Pollution Bulletin, 129 (February), 835-845. https://doi.org/10.1016/j.marpolbul.2017.10 .008

Kwok, C. K., Liang, Y., Leung, S. Y., Wang, H., Dong, Y. H., Young, L., \& Wong, M. H. (2013). Biota-sediment accumulation factor (BSAF), bioaccumulation factor (BAF), and contaminant levels in prey fish to indicate the extent of PAHs and OCPs contamination in eggs of waterbirds. Environmental Science and Pollution Research, 20(12), 8425-8434. https://doi.org/10.1007/s11356013-1809-4

Link, A. G. (1966). Textural classification of sediments. Sedimentology. https://doi.org/ 10.1111/j.1365-3091.1966.tb01598.x

Long, E. R., \& Mogran, L. G. (1990). The potential for biological effects of sedimen-sorbed contaminants tested in the national status and trends program. Seattle, Washington.

Neff, J. M. (2002). Bioaccumulation in marine organisms : effect of contaminans from oil well Produced Water. Elsevier (1st ed., Vol. 468). Massachusetts: Elsevier. https:// doi.org/https://doi.org/10.1016/B978-0-08043716-3.X5000-3

Nordborg, F. M., Flores, F., Brinkman, D. L., Agustí, S., \& Negri, A. P. (2018). Phototoxic effects of two common marine fuels on the settlement success of the coral Acropora tenuis. Scientific Reports, 8(1), 8635. https://doi.org/10.1038/s41598-018-269727

Okop, I. J., \& Ekpo, S. C. (2012). Determination of Total Hydrocarbon Content in Soil after Petroleum Spillage. Proceedings of the World Congress on Engineering, 3, 2-6.

Pakpahan, A., \& Syafa'at, N. (1991). Hubungan Konservasi Tanah dan Air dengan Komoditas Yang Diusahakan, Struktur Pendapatan serta Karakteristik Rumah Tangga. Jurnal Agro Ekonomi, 10(1), 1-15. https://doi.org/http://dx.doi.org/10.21082/ja e.v10n1-2.1991.1-15

Ramadass, K., Megharaj, M., Venkateswarlu, K., \& Naidu, R. (2017). Toxicity of diesel water accommodated fraction toward microalgae, Pseudokirchneriella subcapitata and Chlorella sp. MM3. Ecotoxicology and Environmental Safety, 142 (April), 538-543. https://doi.org/10.1016/j.ecoenv.2017.04.05 2

Rauckyte, T., Żak, S., Pawlak, Z., \& Oloyede, A. (2010). Determination of Oil and Grease, Total Petroleum Hydrocarbons and Volatile Aromatic Compounds in Soil and Sediment Samples. Journal of Environmental Engineering and Landscape Management, 18(3), 163-169. https://doi.org/ 10.3846/jeelm.2010.19

Rullyanto, A., Suprijo, T., \& Riandini, F. (2007). Pemodelan Transport Sedimen Kohesif di Muara Sungai Cimanuk, Indramayu. JTM, $X V I I(2), 73-81$. Retrieved from pemodelan transport sedimen kohesif di muara sungai cimanuk .www.bgl.esdm.go.id/publication/ index.php/dir/article/588

Savitri, E., \& Pramono, I. B. (2017). Analisis Banjir Cimanuk Hulu 2016. Jurnal Penelitian Pengelolaan Daerah Aliran Sungai, 1(2), 97-110. https://doi.org/ http://dx.doi.org/10.20886/jppdas.2017.1.2. 97-110

Setiawan, W. B. (2017). Potensi Bencana Geologi di Kawasan Delta Cimanuk, Kabupaten Indramayu, Jawa Barat. Dalam Seminar Nasional Kelautan XII " Inovasi Hasil Riset dan Teknologi dalam Rangka Penguatan Kemandirian Pengelolaan Sumber Daya Laut dan Pesisir" (pp. 14-24). Surabaya: Universitas Hang Tuah. Retrieved from http://www.jostronik.com/seminakel/file/pr osiding2017/komisi_B/3. Wahyu S.pdf

Simpson, S. L., Batley, G. E., \& Chariton, A. A. (2013). Revision of the ANZECC/ ARMCANZ sediment quality guidelines. CSIRO Land and Water Science Report 
08/07.

Sodikin. (2011). Karakteristik dan Pemanfaatan Sumberdaya Pesisir dan Laut di Kawasan Pantai Kabupaten Indramayu. Gea, 11(2), 200-208. Retrieved from http://ejournal.upi.edu/index.php/gea/article /view/1630

Speight, J. (2014). The Chemistry and Technology of Petroleum, Fifth Edition. https://doi.org/10.1201/b16559

Suhery, N., Damar, A., \& Effendi, H. (2017). Indeks Kerentanan Ekosistem Terumbu Karang Terhadap Tumpahan Minyak: Kasus Pulau Pramuka dan Pulau Belanda di Kepulauan. Jurnal Ilmu dan Teknologi Kelautan Tropis, 9(1), 67-90.

Sulaksana, N., Sukiyah, E., Sjafrudin, A., \& Haryanto, E. T. (2013). Karakteristik Geomorfologi Das Cimanuk Bagian Hulu dan Implikasinya Terhadap Intensitas Erosi serta Pendangkalan Waduk Jatigede. Bionatura-Jurnal Ilmu-Ilmu Hayati dan Fisik, 15(2), 100-106.

Sumatera, M. (1982). Insecticide residue monitoring in sediments water fish and mangroves at the Cimanuk Delta. Majalah $B A T A N$, 15(12), 15-30. Retrieved from xhttps://inis.iaea.org/search/searchsinglerec ord.aspx? recordsFor $=$ SingleRecord \&RN $=1$ 5038665

Susetyaningsih, A. (2012). Pengaturan Penggunaan Lahan di Daerah Hulu DAS Cimanuk sebagai Upaya Optimalisasi Pemanfaatan Sumberdaya Air. Jurnal Konstruksi Sekolah Tinggi Teknologi Garut, 10(01), 1-8. Retrieved from http://jurnal.sttgarut.ac.id/index.php/konstru ksi/article/download/107/94

Sutriati, A. (2011). Penilaian Kualitas Air Sungai dan Potensi Pemanfaatannya Studi Kasus Sungai Cimanuk. Jurnal Sumber Daya Air, 7(1), 1-17.

Tehrani, G. M., Hashim, R., Sulaiman, A. H., Sany, B. T., Salleh, A., Jazani, R. K., \& Barandoust, R. F. (2013). Distribution of total petroleum hydrocarbons and polycyclic aromatic hydrocarbons in Musa bay sediments (Northwest of the Persian Gulf). Environment Protection Engineering, 39(1), $115-128$. https://doi.org/10.5277/EPE130109

Webby, A., \& Ling, N. (2016). Acute sublethal toxicity of MV Rena contaminants (heavy fuel oil, oil dispersant and cryolite) to finfish and rock lobster. New Zealand Journal of Marine and Freshwater Research, 50(1), 144-158.

https://doi.org/10.1080/00288330.2015.110 4366

Wentworth, C. K. (1922). A Scale of Grade and Class Terms for Clastic Sediments. Journal of Geology, 30(5), 377-392. Retrieved from https://www.jstor.org/stable/30063207

Yi, Y. M., Park, S., Munster, C., Kim, G., \& Sung, K. (2016). Changes in Ecological Properties of Petroleum Oil-Contaminated Soil After Low-Temperature Thermal Desorption Treatment. Water, Air, \& Soil Pollution, 227(4), 108. https://doi.org/10.1007/s11270-016-2804-4

Yogaswara, D., \& Khozanah. (2018). Distribusi Spasial Total Petroleum Hidrokarbon ( TPH ) dalam Sedimen Laut Sumba, Nusa Tenggara Timur. Oseanologi dan Limnologi di Indonesia, 3(2), 173-181.

Yu, C., Kamboj, S., Wang, C., \& Cheng, J. J. (2015). Data Collection Handbook to Support Modeling Impacts of Radioactive Material in Soil and Building Structures. Argonne, IL (United States). https://doi.org/10.2172/1224969.

Zhou, R., Qin, X., Peng, S., \& Deng, S. (2014). Total petroleum hydrocarbons and heavy metals in the surface sediments of Bohai Bay, China: Long-term variations in pollution status and adverse biological risk. Marine Pollution Bulletin, 83(1), 290-297. https://doi.org/10.1016/j.marpolbul.2014.03 .003 